\title{
FLORA MALESIANA PRECURSOR FOR THE TREATMENT OF MORACEAE 8: OTHER GENERA THAN FICUS
}

\author{
C.C. BERG \\ Bergen Museum, University of Bergen, Allégate 41, 5007 Bergen, Norway; \\ Nationaal Herbarium Nederland, Universiteit Leiden branch, \\ P.O. Box 9514, 2300 RA Leiden, The Netherlands.
}

\begin{abstract}
SUMMARY
The tribe Artocarpeae is redefined, the tribe Soroceae is established by change of rank, and as a consequence a new tribe Antiaropsidae is established. Moreover, a new species Antiaropsis uniflora C.C. Berg is described. In Artocarpus a new species is described, A. albobrunneus C.C. Berg, one subspecies is raised to the rank of species, A. brevipedunculatus (F.M. Jarrett) C.C. Berg, and new subspecies are described in several species, A. longifolius Becc. subsp. adpressus C.C. Berg, A. teijsmannii Miq. subsp. subglabrus C.C. Berg. In Prainea, P. papuana is reduced to a subspecies, P. limpato (Miq.) K. Heyne subsp. papuana (Becc.) C.C. Berg. In Streblus the sections Pseudomorus (Bureau) Corner and Taxotrophis (Blume) Corner are reinstated, S. urophyllus is reduced to a subspecies, S. glaber (Merr.) Corner subsp. urophyllus (Diels) C.C. Berg, in S. streblus var. australianus is raised to S. glaber subsp. australianus (C.T. White) C.C. Berg, and S. celebensis C.C. Berg is described as a new species.
\end{abstract}

Key words: Moraceae, Artocarpeae, Antiaropsis, Artocarpus, Prainea, Streblus, Malesia.

\section{INTRODUCTION}

A precursory study on Moraceae focussed on its classification and the Asian representatives was published by Corner in 1962. It was preceded by a monographic study on Artocarpus and allied genera by Jarrett (1959a, b, c, 1960a, b). Corner's study was succeeded by some publications of new species for the Malesian region (Corner, 1970, 1975, 1976; Go, 1998; Kochummen, 1998) and studies by Berg $(1986,1988)$ dealing with delimitation of genera and tribes.

\section{SUBDIVISION OF MORACEAE}

The subdivision of the family into the tribes Artocarpeae, Castilleae, Dorsteniaeae, Ficeae, and Moreae as proposed by Berg $(1988,1998)$ is changed for the current treatment of the family for Flora Malesiana dividing the heterogeneous tribe Artocarpeae into three homogeneous tribes more equivalent to the other tribes, as suggested (Berg, 2001) or proposed (Berg, 2005b), but now formalized.

Artocarpeae R.Br. (1818) 454

Trees or shrubs (or climbers?), monoecious or dioecious, with or without uncinate hairs. Leaves alternate and spirally arranged or distichous; stipules fully amplexicaul 
to lateral or intrapetiolar, free or connate. Inflorescences usually unisexual, axillary or cauliflorous, spicate to capitate and then clavate, globose, or discoid, pedunculate, bracteate; interfloral bracts often peltate or subpeltate varying to spathulate, clavate, rod-shaped to spine-shaped; staminate flowers numerous, with 2-4 connate tepals, stamens $1-4$, straight in the bud, pistillode rarely present; pistillate flowers numerous to few, free or connate, tepals 2-4(-5) and connate or absent (in Treculia), ovary free or adnate to the perianth, stigmas 1 or 2 . Fruit large, free, with a dry pericarp or \pm drupaceous, indehiscent, enveloped by a fleshy perianth or embedded in the pulpy part of the infructescence. Seed without or with scanty endosperm, embryo curved or straight, with thick, equal or unequal cotyledons.

This tribe comprises five clearly related genera, Artocarpus (40-45 spp. in quite distinct subgenera: Artocarpus and Pseudojaca), Hullettia (2 spp.), Parartocarpus (2 spp.), and Prainea (2 spp.) in Asia (and the Pacific), and Treculia (3 spp.) in Africa. Artocarpus, Parartocarpus, and Prainea are very closely related; one could consider to unite them in a single genus with four subgenera: Artocarpus, Parartocarpus, Prainea, and Pseudojaca.

\section{Antiaropsideae C.C. Berg, trib. nov.}

Arbores dioeciae. Inflorescentiae discoideae involucro bractearum imbricatarum basaliter connatarum vel urceolato bracteis dispersis basaliter connatis. Drupa dehiscens. - Typus: Antiaropsis.

Trees, dioecious, without uncinate hairs. Leaves alternate and distichous or laxly spirally arranged; lamina entire; venation subscalariform to reticulate; stipules free, lateral or to (almost?) fully amplexicaul. Inflorescences axillary, unisexual; receptacle discoid to urceolate, involucrate with imbricate or with few \pm scattered, basally attached bracts, possibly interfloral bracts in Antiaropsis. Staminate flowers free, numerous to several, tepals 4-6, free, stamens (2-)4-6, straight in the bud, pistillode present. Pistillate flowers free, numerous to several or one, tepals 4-6, ovary free, stigmas filiform, 2 and equally or unequally long or 1. Fruit a dehiscent drupe. Seed without endosperm, embryo curved, cotyledons equal, rather thick, folded.

The tribe comprises two genera, Antiaropsis, confined to New Guinea, with two species, and Sparattosyce, confined to New Caledonia, with one (or two?) species.

In the structure of the inflorescences the tribe shows similarities to the tribe Castilleae from which it clearly differs in the absence of connate tepals, the non-fleshy tepals of pistillate flowers in fruit, the free dehiscent drupes, and the absence of self-pruning branches as part of the architectural model of Cook (Hallé \& Oldeman, 1970; Berg, 1977). A molecular study by Datwyler \& Weiblen (2004) on relationships in Moraceae suggests that this tribe has affinities to the tribes Castilleae and Ficeae. These tribes share basally attached bracts which character allows formation of involucrate receptacles or concentrations of bracts on the margins of receptacles closing off more or less the interior of the inflorescence and, therewith, may play a role in pollination as by fig wasps or thrips (Sakai, 2001; Zerega et al., 2004). However, involucrate receptacles are also found in Trophis (see Berg, 2001). Antiaropsideae and Castilleae have strictly unisexual inflorescences by which they essentially differ from the Ficeae with (basically) 
bisexual inflorescences. These inflorescences show in the position and anthesis of the staminate and pistillate flowers still the basically cymose structure of the inflorescence in contrast to those of the other two tribes.

In the pistillate inflorescences of Antiaropsis decipiens, in addition to the structures which are clearly tepals, similar structures, somewhat larger and flat, occur on the receptacle; they could be regarded as interfloral bracts, but they might be 'displaced' tepals. Such 'interfloral bracts' might be present in staminate inflorescences, but they could not be detected in the material available.

Sparattosyce has been linked to Ficus, but Corner (1962) included both Antiaropsis and Sparattosyce in the Castilleae (previously Olmedieae), later, 1978, he made a functional link to the long-styled species of Ficus subsect. Macrostyla (see Berg, 2004). However, the long style of Ficus macrostyla Corner and F. squamosa Roxb. is likely a secondary adaptation to the rheophytic life-form of these species and not a link to an early stage of evolution of the syconium.

The cardenolides $\alpha$-antiarin and antioside known from Antiaris have also been found in seeds of Antiaropsis (Bisset, 1957: 219); this may indicate affinities of Antiaropsis to the Castilleae. On the other hand, cardenolides are also detected in Streblus asper Lour. (Hegnauer, 1969).

Tribe Soroceae (Miq.) C.C. Berg, stat. nov.

Subtribe Soroceae Miq. (1853) 82, 112. - Type: Sorocea A. St.-Hil.

Trees or shrubs, dioecious (or monoecious), sometimes with uncinate hairs. Leaves alternate and distichous or opposite (in Bagassa); lamina entire to lobate; tertiary venation scalariform to reticulate; stipules free, lateral or fully amplexicaul. Inflorescences unisexual, axillary (or cauliflorous). Staminate inflorescences racemose to spicate (to subcapitate), bracteate with peltate to basal attached bracts or ebracteate; staminate flowers clearly to weakly defined with 2-4 tepals, free or basally connate; stamens $1-4$, straight in the bud, pistillode usually absent. Pistillate inflorescences racemose to spicate to globose capitate or uniflorous with 4 connate tepals, fleshy in fruit; ovary free or fused with the perianth. Fruit an indehiscent drupe or a pseudodrupe (the fruit enclosed by a fleshy perianth), solitary or in globose heads. Seed small and with endosperm or large and without endosperm, embryo straight or curved, cotyledons equal or (very) unequal, flat or thick.

The tribe is confined to the Neotropics and comprises five genera: Bagassa (1 sp.), Batocarpus (3 spp.), Clarisia (3 spp.), Poulsenia (1 or 2? spp.), and Sorocea (14 spp.).

In the structure of the inflorescences, the tribe shows similarities to the tribe Moreae from which it differs in the stamens that are not inflexed before anthesis, the absence of pistillodes, and the frequent reduction of the number of stamens.

The tribe is rather diverse. The most peculiar genus is Poulsenia with prickles unique in the family and with elongate pluricellular trichomes also found in Ficus. Moreover, the stipules are relatively large and fully amplexicaul.

In the cladogram based on molecular analyses by Datwyler \& Weiblen (2004) the genera included in the Soroceae are mixed with those of the Moreae, with the exception of Poulsenia which got nested in the Castilleae. 


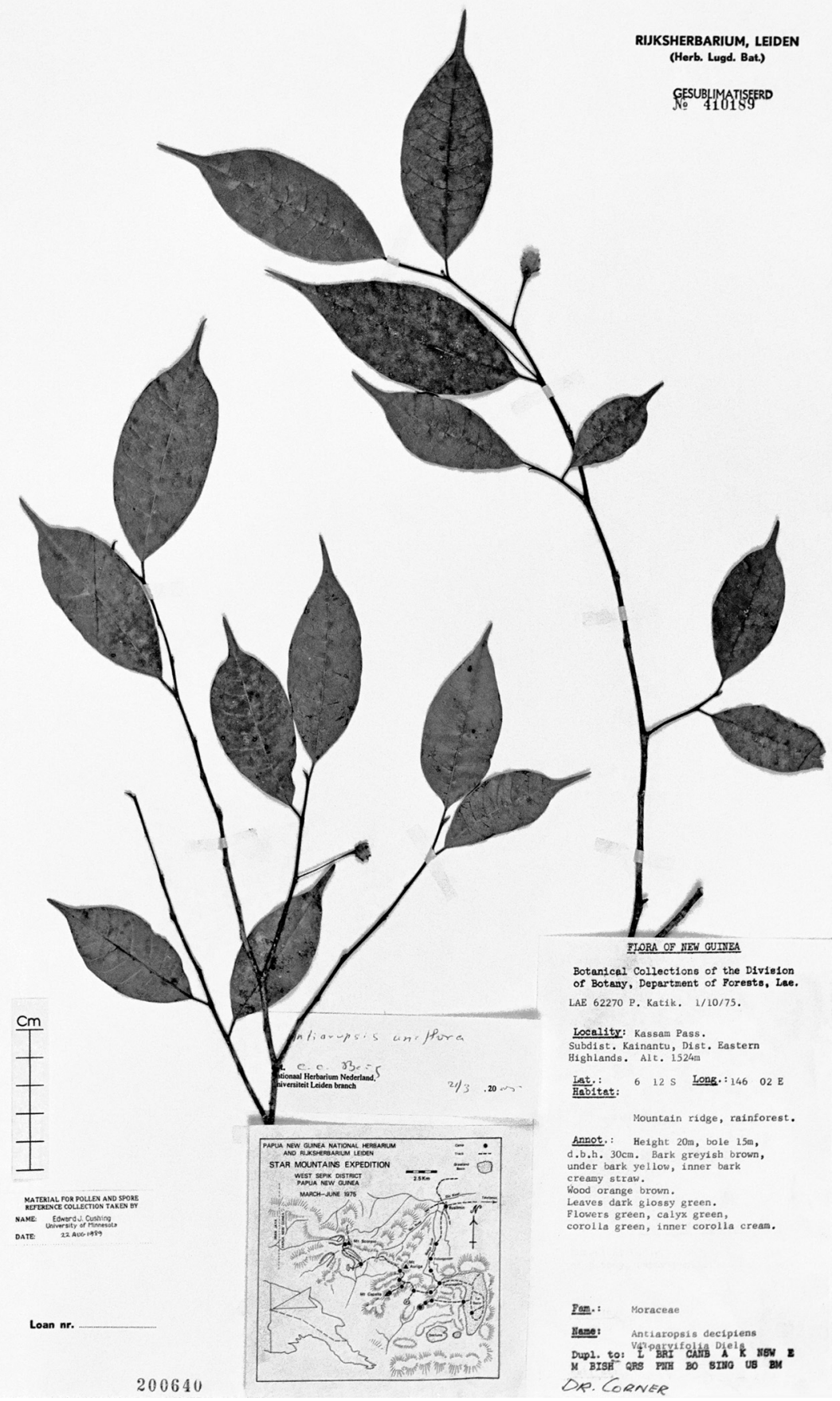

Fig. 1. Antiaropsis uniflora C.C. Berg. Leafy twigs with pistillate inflorescences (P. Katik LAE 62270, L), Papua New Guinea, Eastern Highlands Prov., Kainantu Subprov., Kassam Pass, 1524 m, 1 Oct. 1975. 


\section{ANTIAROPSIS}

Antiaropsis from New Guinea was regarded as monotypic by Corner (1962): A. decipiens K. Schum. with a variety parvifolia, being distinct in the smaller lamina and the smaller number of lateral veins. As the type of the variety could not be examined, it is not certain whether it matches the collections used to describe the new species, A. uniflora, which is consistently distinct from lowland material included in A. decipiens in the habit, growing into trees of more than $20 \mathrm{~m}$ tall, the small leaves, up to 10 $\mathrm{cm}$ long, the lack of bracts on the peduncle of the pistillate inflorescences, the broader and more densely hairy involucral bracts, and the presence of a single flower, features allowing recognition at the species level.

\section{Antiaropsis uniflora C.C. Berg, spec. nov. - Fig. 1}

Antiaropside decipienti in laminis parvis $3-10 \mathrm{~cm}$ longis, inflorescentia pistillata uniflora, pedunculo sine bracteis differt. - Typus: P. Katik LAE 62270 (holo LAE; iso K, L, according to the label also in A, BISH, BM, BO, BRI, CANB, E, M, NSW, PNH, QRS, SING, and US), Papua New Guinea, Eastern Highlands Prov., Kainantu Subprov., Kassam Pass, 1524 m, 1 Oct. 1975.

Trees up to $23 \mathrm{~m}$ tall. Leafy twigs 1-2 mm thick, appressed puberulous. Leaves distichous; lamina oblong to elliptic, $3-10$ by $1.5-3.5 \mathrm{~cm}$, coriaceous to subcoriaceous, base (sub)cuneate, margin entire, apex acuminate to subcaudate, upper surface glabrous, lower surface sparsely appressed-puberulous on the main veins, smooth, midrib prominent above, lateral veins $8-12$ pairs, tertiary venation reticulate; petiole $0.4-0.8 \mathrm{~cm}$ long, sparsely puberulous; stipules $0.2-0.4 \mathrm{~cm}$ long, puberulous, caducous. Staminate inflorescences unknown. Pistillate inflorescences axillary, solitary; peduncle 1-2.5 cm long, puberulous, without bracts; head discoid, c. $0.5 \mathrm{~cm}$ diameter, in fruit up to c. $1 \mathrm{~cm}$ diameter; involucral bracts in 4 or 5 rows, semicircular to oblong, 2-8 $\mathrm{mm}$ long, densely white appressed-puberulous, the inner ones obtuse. Flower one; tepals 4, oblong to elliptic, c. $5 \mathrm{~mm}$, in fruit up to $10 \mathrm{~mm}$ long, \pm conduplicate, appressed-puberulous, in fruit orange to red; style 1.5-2 mm long, stigmas filiform, 1.5-2 mm long. Endocarp body ellipsoid, c. $0.7-0.8 \mathrm{~cm}$ long.

Distribution - New Guinea.

Habitat - Forest; at altitudes between c. 1400 and $3200 \mathrm{~m}$.

Notes - 1. As the type of Antiaropsis decipiens K. Schum.var. parvifolia Diels (1935), Römer 867, Papua New Guinea, 'Hellwig-Gebirge', 750 m, Nov. 1909, is not extant, it is not certain whether it belongs to this species or is just a small-leaved specimen of A. decipiens.

2. The contrasting colours (black of the endocarp, white of the exocarp, red of the tepals) found in Antiaropsis decipiens probably also occur in the new species in inflorescences in fruiting state.

3. Other specimens examined: E.E. Henty et al. NGF 29239 (L), Papua New Guinea, Eastern Highlands Prov., Kainantu Subprov., Kassam Pass, c. 1300 m, 11 Jan. 1968, and H. Streimann et al. 26093 (L), Papua New Guinea, Eastern Highlands Prov., Kainantu Subprov., Kassam Pass, c. 1650 m, 15 Dec. 1965. 


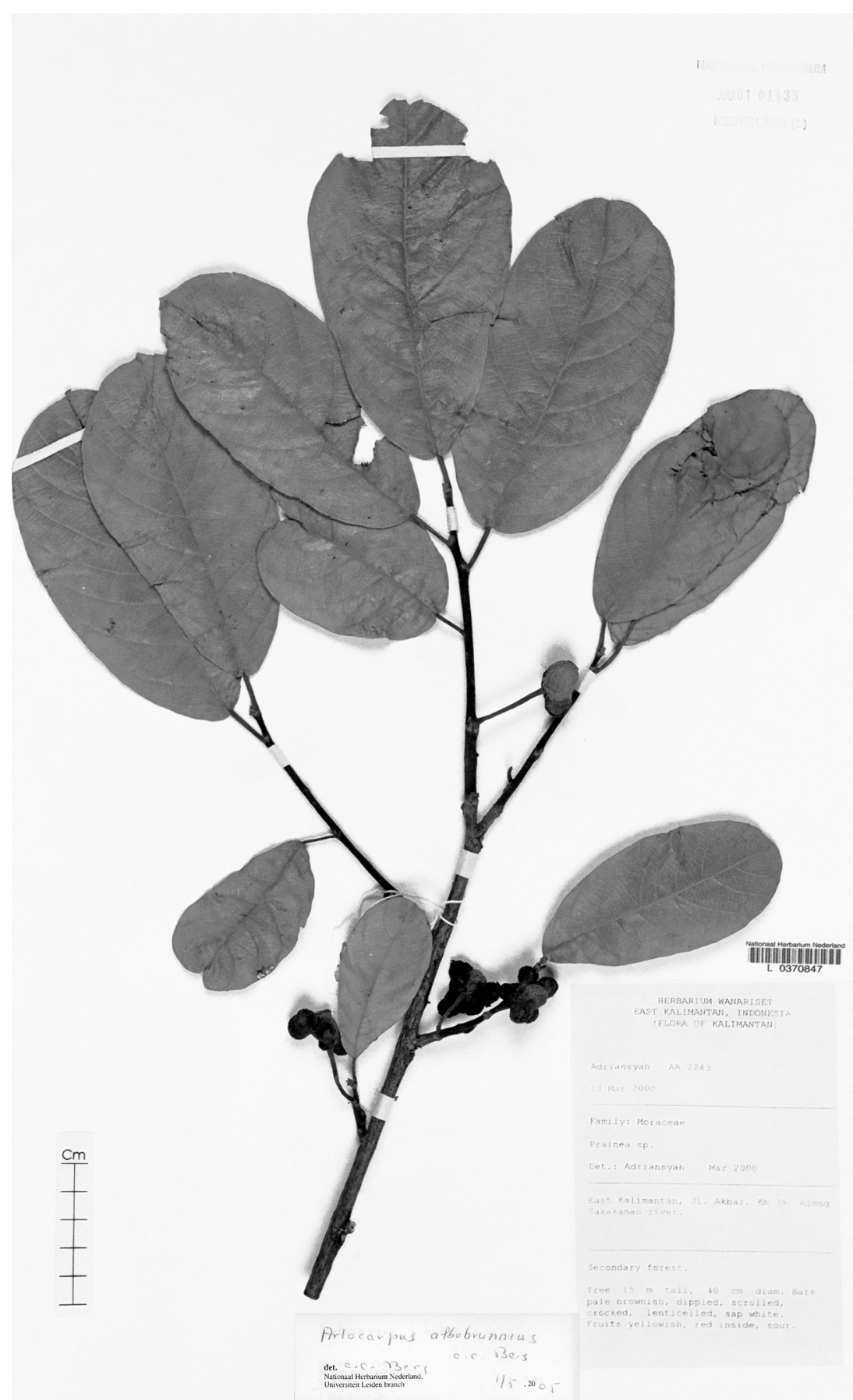

Fig. 2. Artocarpus albobrunneus C.C. Berg. Leafy twigs with infructescences (Adriansyah AA 2234, L), Indonesia, East Kalimantan, Sakakanan River, Jl. Akbar, Km 39, March 2000. 


\section{ARTOCARPUS}

Artocarpus albobrunneus C.C. Berg, spec. nov. - Fig. 2

Lamina coriacea apice rotundo, infructescentia in centro albide velutina peripheria rubrobrunea. - Typus: Adriansyah AA 2243 (holo WAN; iso K, L), Indonesia, East Kalimantan, Sakakanan River, Jl. Akbar, Km 39, 13 March 2000.

Tree $15 \mathrm{~m}$ tall, evergreen (?). Leafy twigs $2-3 \mathrm{~mm}$ thick, sparsely minutely brown puberulous, towards the bases of the petiole more densely hairy, smooth, drying dark brown to blackish. Leaves distichous; lamina coriaceous, oblong to elliptic to subobovate, $6-13$ by $2.5-6.5 \mathrm{~cm}$, base rounded to cordulate, slightly inaequilateral, margin entire, \pm revolute (towards the base), apex rounded, upper surface minutely brownish puberulous mainly on the midrib, smooth, lower surface minutely brownish puberulous in the main veins to whitish puberulous on the smaller veins, smooth, lateral veins 7-9(-10) pairs, none of them furcate far from the margin, tertiary venation scalariform, (and also the smaller veins) prominent; petiole $0.8-1.5 \mathrm{~cm}$ long, 1-1.5 mm thick, densely minutely brown puberulous, the epidermis flaking off; stipules lateral, 0.2-0.4 cm long, brownish puberulous, caducous. Staminate inflorescences not seen. Pistillate inflorescences axillary, solitary; (in fruit) peduncle $1.5-2.5 \mathrm{~cm}$ long, densely brownish puberulous; head subglobose (?); stigma simple; interfloral bracts peltate, the apical part c. $0.2 \mathrm{~mm}$ diameter, puberulous, persistent in the central part of the infructescence, largely caducous in the peripheral part. Infructescences discoid and strongly lobed around the fruits, central part whitish velutinous, peripheral part (lobes) red-brown velutinous.

Note - This species is unusual among the species of Artocarpus subg. Pseudojaca in the coriaceous lamina that dry greenish. The different colours of part of the infructescence are strange - a way to create contrasting colours to attract dispersers? These remarkable features mean that even a single collection is enough to establish a new species. The shape of the infructescence is sometimes also found in Artocarpus lacucha Buch.-Ham., e.g., in D.D. Soejarto et al. 7691 (L) from Palawan (Philippines), which could be an indication of the affinities of the new species.

\section{Artocarpus brevipedunculatus (F.M. Jarrett) C.C. Berg, stat. nov.}

Based on Artocarpus melinoxylus Gagnep. subsp. brevipedunculatus F.M. Jarrett (1959c) 144. - Type: G.H.S. Wood SAN A-1733 (holo K n.v.; iso A, L, according to the label also in BO, BRI, KEP, and SING), Borneo, Sabah, 1/2 mile NE of Beaufort, 6 May 1955.

Jarrett (1959c) included Bornean material in Artocarpus melinoxylus Gagnep. from Indochina. That material was kept in subsp. brevipedunculatus, but it is morphologically sufficiently distinct and phytogeographically separated to be treated as a species, distinct not only in shorter peduncles and smaller heads of the staminate inflorescence, but also in the cuneate to obtuse base of the lamina, the absence of ramification of the lateral veins and the shorter stipules.

\section{Artocarpus longifolius Becc.}

In a comment on this species, Jarrett (1960a) noted subglabrous specimens assuming that they represented (sub)juvenile material. However, two of the specimens examined, 


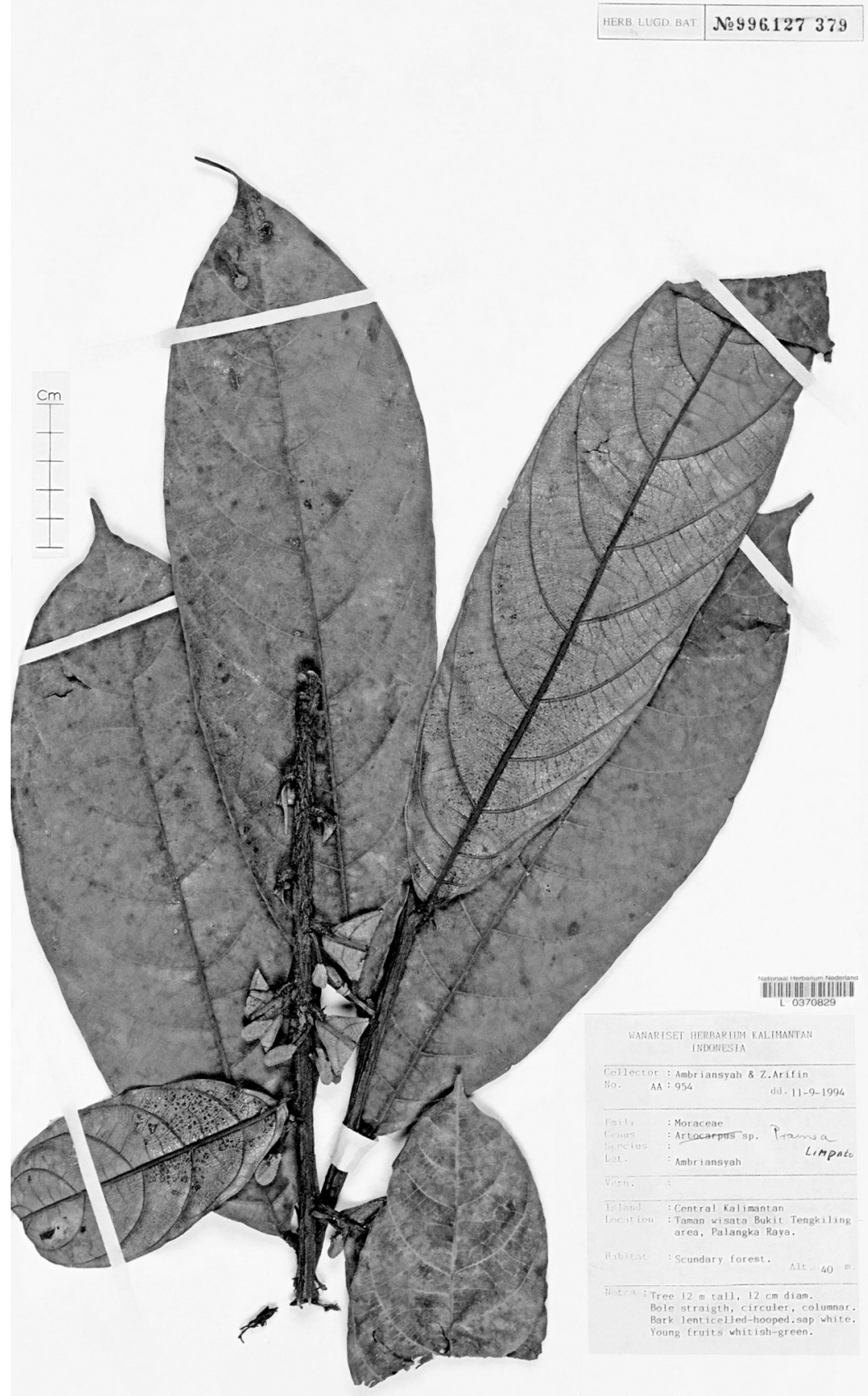

Fig. 3. Artocarpus longifolius Becc. subsp. adpressus C.C. Berg. Leafy twigs with staminate inflorescences (Ambriansyah \& Z. Arifin AA 954, L), Indonesia, Kalimantan, Taman Wisata, Bukit Tengkiling area, Palangka, 11 Sept. 1994. 
with sparsely hairy leafy twigs and laminas, bear staminate or pistillate inflorescences, the former largely similar to those of material with \pm densely hairy leafy twigs and lower surface of the lamina, the latter with a much shorter, c. $0.3 \mathrm{~cm}$ long peduncle, in \pm densely hairy specimens $2-6 \mathrm{~cm}$ long. These differences in indumentum (possibly linked to shorter peduncles of the pistillate inflorescences) allow distinction of subspecies, possibly eventually to separate as closely related species with short petioles with exfoliating epidermis and abundant uncinate hairs in common. More material is needed to sort out the status of these two morphological entities which are sympatric and apparently have a similar ecology.

\section{Artocarpus longifolius Becc. subsp. longifolius}

Lower surface of the lamina \pm densely brownish puberulous to hirtellous, partly with uncinate hairs, midrib, lateral and tertiary veins mostly \pm impressed above.

Distribution - Borneo.

Artocarpus longifolius Becc. subsp. adpressus C.C. Berg, subsp. nov. - Fig. 3

A subspecie typica laminis infra pilis pluribus adpressis differt. - Typus: Ambriansyah \& Z. Arifin AA 954 (holo WAN; iso L), Indonesia, Kalimantan, Taman Wisata, Bukit Tengkiling area, Palangka, 11 Sept. 1994 (m).

Lower surface of the lamina sparsely brownish to whitish appressed puberulous on the main veins, intermixed with patent to retrorse uncinate hairs, subhispidulous on the smaller veins, main veins not (never?) impressed above.

Distribution - Borneo (Brunei, Central Kalimantan).

Note - Additional collection: N. Nagkat et al. BRUN 15511 (L), Brunei, Tutong, Telisai, Bukit Basong, 9 Nov. 1994 (f). The leaves of this collection are small (9-13 by $3.5-6 \mathrm{~cm})$ and have few lateral veins $(5-7$ pairs $)$.

\section{Artocarpus teijsmannii Miq. subsp. teijsmannii}

Leafy twigs, leaves, and stipules whitish to brownish minutely appressed-puberulous; stipules brown subsericeous to comose at the apex. Peduncle minutely puberulous. Apex of the pistillate flower pyramidate, puberulous. Pistillate flowers intermixed with subulate, 1-2 mm long 'processes'.

Distribution - Thailand, Nicobar Islands, Sumatra, Peninsular Malaysia, Borneo, Sulawesi, Moluccas (Ceram, Sula Islands), New Guinea (western).

Artocarpus teijsmannii Miq. subsp. subglabrus C.C. Berg, subsp. nov. - Fig. 4

A subspecie typica in ramulis foliosis atque stipulis foliisque omnibus glabris differt. - Typus: L.S. Smith NGF 1176 (holo LAE; iso CANB), Papua New Guinea, Morobe Prov., Nadzab area, Dec. 1944 (m and f).

Leafy twigs, leaves, and stipules glabrous. Peduncle glabrous or with few uncinate hairs. Apex of pistillate flower cushion-shaped and minutely puberulous or pyramidate and puberulous only terminally. Pistillate flowers intermixed with peltate bracts with apices $0.3-0.5 \mathrm{~mm}$ diameter or very few c. $1.5 \mathrm{~mm}$ long subulate 'processes'. 


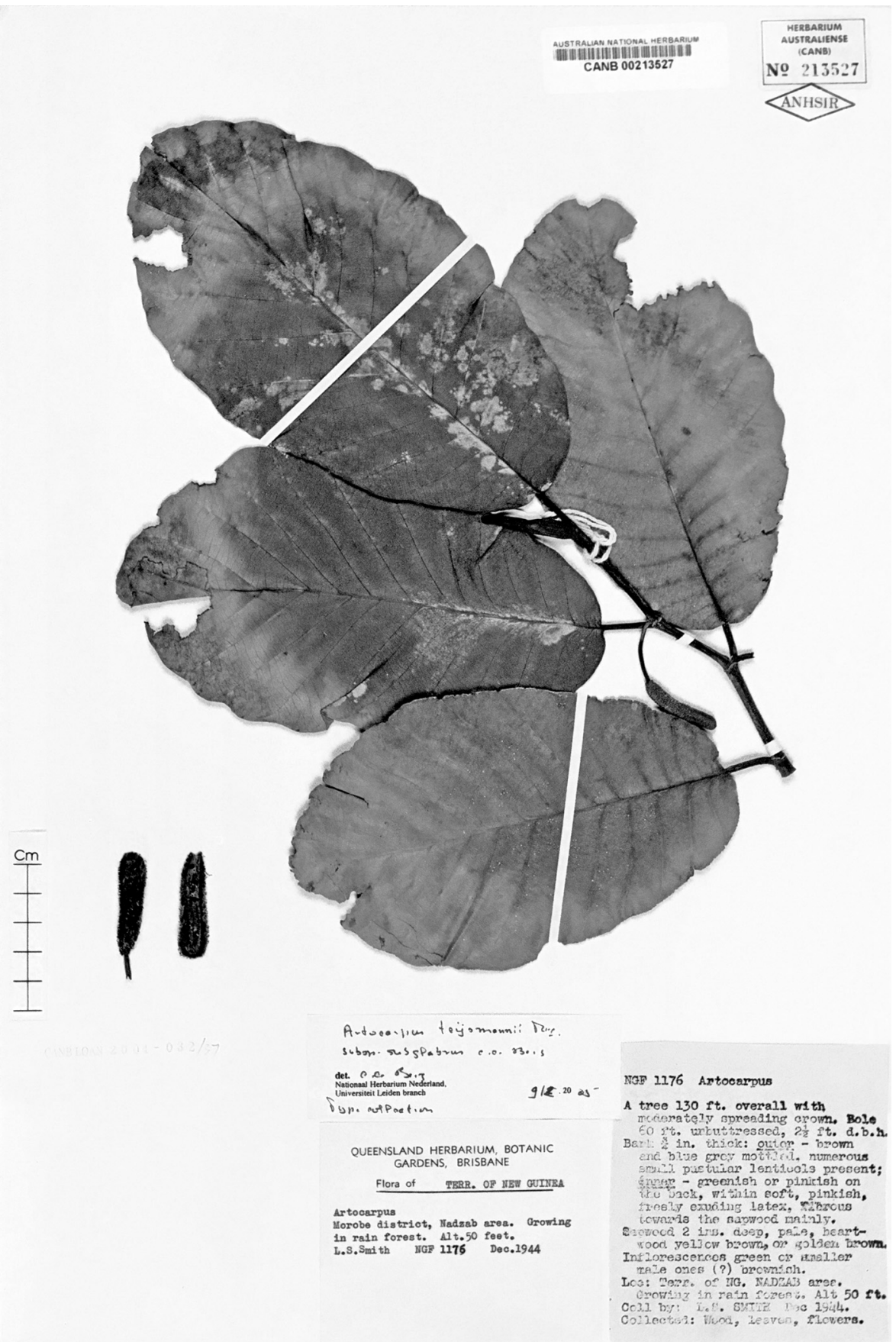

Fig. 4. Artocarpus teijsmannii Miq. subsp. subglabrus C.C. Berg. Leafy twig with staminate inflorescence and separate pistillate inflorescence (L.S. Smith NGF 1176, CANB), Papua New Guinea, Morobe Prov., Nadzab area, Dec. 1944. 
Distribution - Papua New Guinea (Bismarck Archipelago, Morobe Province), Solomon Islands (Guadalcanal).

Notes -1 . This species is only known from two fertile collections, the type collection and J. Boraule et al. BSIP 9301 (L), Solomon Islands, East Guadalcanal, Makina River, Marau, 9 May 1968. The lectotype of Ficus ralumensis Diels (Berg, 2005a) from the Bismarck Archipelago, consisting of two leaves, almost certainly belongs to this subspecies.

2. The surfaces of vegetative parts bearing short hairs in the typical subspecies are punctate in the type of the new subspecies, but smooth in the collection from the Solomon Islands.

3. The typical subspecies is quite variable with regard to the presence of peltate bracts or cylindrical 'processes' among the flowers and in the stigmas. The single staminate inflorescence known of the new subspecies has peltate interfloral bracts and the pistillate inflorescence of the type has cushion-shaped minutely puberulous apices of the pistillate flowers and peltate interfloral bracts. The collection from the Solomon Islands has pyramidate sparsely puberulous apices of the pistillate flower and few subulate 'processes'. In the type collection the stigmas are bifid and in the collection from the Solomon Islands the stigmas are simple.

\section{PRAINEA}

The four species recognised in this genus by Jarrett (1959b) showed two by two such small and largely quantitative differences that $P$. frutescens Becc. is to be included in $P$. scandens King and $P$. papuana Becc. reduced to a subspecies of P. limpato (Miq.) Beumée ex K. Heyne.

\section{Prainea limpato (Miq.) Beumée ex K. Heyne subsp. limpato}

Lamina often scabridulous beneath; lateral veins (9-)13-20(-25) pairs. Staminate inflorescences: peduncle 2-4(-5) cm long; head 0.8-1.3(-1.5) cm diameter. Pistillate inflorescences: peduncle 7-20(-25) cm long; head 1-2(-2.5) cm diameter. Fruiting perianth ellipsoid to ovoid, (1.2-)1.5-2(-2.5) $\mathrm{cm}$ long.

Distribution - Sumatra, Peninsular Malaysia, Borneo.

Prainea limpato (Miq.) Beumée ex K. Heyne subsp. papuana (Becc.) C.C. Berg, stat. \& comb. nov.

Based on Prainea papuana Becc., For. Born. (1902) 635. - Type: Beccari PP 675 (holo FI n.v.), New Guinea.

Lamina smooth beneath; lateral veins (8-)12-16(-20) pairs. Staminate inflorescences: peduncle $1.5-4 \mathrm{~cm}$ long; head $0.3-0.8 \mathrm{~cm}$ diameter. Pistillate inflorescences: peduncle 2-12 cm long; head (0.5-)0.8-1.5(-1.8) cm diameter. Fruiting perianth subglobose to ovoid, $0.8-1.3(-1.5) \mathrm{cm}$ long.

Distribution - Moluccas, New Guinea. 


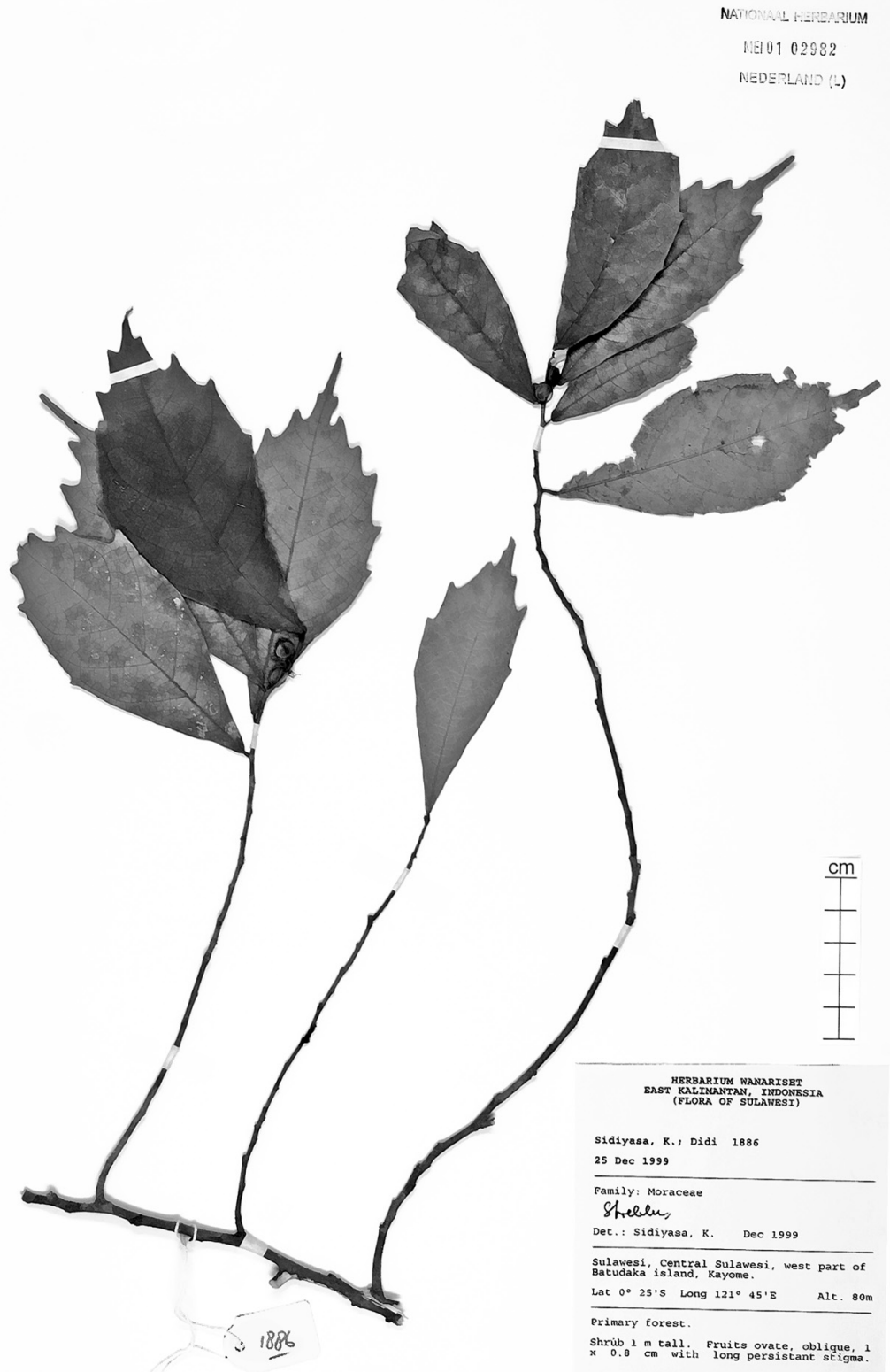

20640

Thind

Fig. 5. Streblus celebensis C.C. Berg. Leafy twigs with pistillate inflorescences (K. Sidiyasa et al. 1886, L), Indonesia, Sulawesi, Batudaka Island, Kayome, Dec. 1999. 


\section{STREBLUS Lour.}

The subdivision of the genus Streblus as proposed by Berg (1988) needs some corrections. The study of the Malesian species made it clear that sect. Pseudomorus (Bureau) Corner is to be reinstated to accommodate $S$. indica (Bureau) Corner and that sect. Streblus sensu Berg is too heterogeneous and that reinstatement of sect. Taxotrophis (Blume) Corner to accommodate the spinose species is appropriate. Section Tetrastigma T.H. Nguyên is to be excluded from the genus as its type Streblus vidalii T.H. Nguyên (1997) is not moraceous but is Aporosa octandra (Buch.-Ham. ex D. Don) A.R. Vickery var. chinensis (Champ. ex Benth.) Schot of the Euphorbiaceae.

\section{Streblus celebensis C.C. Berg, spec. nov. - Fig. 5.}

Frutex espinosus dioecius partibus variis pilis atrofuscis appressis. Inflorescentiae staminatae capitatae subsessiles, tepala in alabastro valvata. Inflorescentiae pistillatae uniflorae, pedunculuque $0.2 \mathrm{~cm}$ longus. - Typus: K. Sidiyasa et al. 1886 (holo WAN; iso K, L), Indonesia, Sulawesi, Batudaka Island, Kayome, Dec. 1999 (f).

Shrub, $1 \mathrm{~m}$ tall, without spines, dioecious. Leafy twigs 1-2 $\mathrm{mm}$ thick, puberulous, mainly with dark brown appressed hairs. Leaves distichous; lamina subcoriaceous, (sub)obovate, $6-15$ by $2-7 \mathrm{~cm}$, base obtuse, margin coarsely crenate-dentate towards the apex; upper surface (subglabrous) smooth, apex acuminate to subcaudate, lower surface sparsely appressed puberulous with dark brown appressed hairs, scabridulous, midrib prominent or prominent in a groove above, lateral veins (7-) 8-10 pairs, tertiary venation subscalariform to reticulate, slightly prominent; petiole $0.3-0.7 \mathrm{~cm}$ long, c. $1 \mathrm{~mm}$ thick, puberulous with dark brown appressed hairs; stipules 1-2 mm long, subpersistent (or caducous). Staminate inflorescences axillary, solitary, subsessile, subcapitate with 3-5 flowers: tepals 4 , valvate in the bud, c. $1.5 \mathrm{~mm}$ long, outside appressed puberulous with dark brown hairs, margin white tomentellous; stamens 4, inflexed in bud, anthers c. $1 \mathrm{~mm}$ long, pistillode obconical, c. $0.5 \mathrm{~mm}$ long; bracts basally attached, ovate, 1-2 mm long, appressed puberulous. Pistillate inflorescences axillary, solitary, uniflorous; peduncle c. $0.2 \mathrm{~cm}$ long; tepals 4 , decussate imbricate, c. $1.5 \mathrm{~mm}$ long, outside appressed puberulous with dark brown hairs, margin white ciliolate; ovary c. $1 \mathrm{~mm}$ long, style c. $3 \mathrm{~mm}$ long, stigmas 2, filiform, 6-8 mm long; bracts few, basally attached, ovate, c. $0.2 \mathrm{~mm}$ long; tepals enlarging and probably partly enveloping the fruit at full maturity.

Notes -1 . This species belongs to sect. Streblus as redefined above and shows similarities in particular to the African S. usambarensis (Engl.) C.C. Berg (1977, 1988). It is apparently an element of rain forest undergrowth. The developing fruits are too young to describe with certainty the position of the tepals in the mature state of the fruit.

2. Section Streblus now comprises four species, including the widespread S. asper Lour. and S. tonkinensis (Eberh. \& Dubard) Corner (incl. S. monoicus Gagnep. = S. asper var. monoicus (Gagnep.) Corner) from Laos and Vietnam.

3. Additional collection examined: K. Sidiyasa et al. 1887 (K, L), Indonesia, Sulawesi, Batudaka Island, Kayome, Dec. 1999 (m). 


\section{Streblus glaber (Merr.) Corner}

Within Streblus glaber, three subspecies are currently recognised, by reduction of $S$. urophyllus, to a subspecies and as a consequence raising the rank of var. australianus to that of subspecies.

\section{Streblus glaber (Merr.) Corner subsp. glaber}

Tree up to $25(-40) \mathrm{m}$ tall. Lamina oblong to elliptic or to lanceolate, (1.5-)3-16 by $(0.5-) 1-4.5 \mathrm{~cm}$, margin of the lamina usually entire, but sometimes dentate in the upper part of the lamina (in Borneo: Sabah); lateral veins 7-18 pairs.

Distribution - Peninsular Malaysia, Sumatra, Borneo (mainly Sabah), Philippines (Luzon, Mindoro, Negros), Sulawesi, Moluccas (Aru Islands), and New Guinea; extending to the Solomon Islands.

Habitat - Montane forest, sometimes on limestone or in relatively dry areas; mostly at altitudes between 700 and $2500 \mathrm{~m}$, rarely down to sea level.

Note - In the Philippines, the inflorescences are usually longer (up to $3 \mathrm{~cm}$ long) and both staminate and pistillate inflorescences tend to have more flowers, often more than 15 or 3 , respectively.

Streblus glaber (Merr.) Corner subsp. australianus (C.T. White) C.C. Berg, stat. nov.

Based on Paratrophis australiana C.T. White (1933) 15. - Streblus glaber (Merr.) Corner var. australianus (C.T. White) Corner (1962) 221; Chew (1989) 18. - Type: Kajewski 1378 (holo A), Australia, Queensland, Herberton Range, 19 Nov. 1929.

Tree up to $20 \mathrm{~m}$ tall. Lamina oblong to subovate, $3-13$ by $1-3.5 \mathrm{~cm}$, margin of the lamina usually crenate-dentate (or also lobate); lateral veins (6-)10-15 pairs.

Distribution - Australia (NE Queensland).

Habitat - Rain forest; at altitudes up to $1000 \mathrm{~m}$.

Streblus glaber (Merr.) Corner subsp. urophyllus (Diels) C.C. Berg, stat. \& comb. nov.

Based on Streblus urophyllus Diels, Bot. Jahrb. Syst. 67 (1935) 172. - Type: E. Mayr 791 (holo B), New Guinea, Saruwaged, Mongi-Busu, 2600 m, March 1929.

Shrub or tree up to $15 \mathrm{~m}$ tall. Lamina oblong to elliptic to subovate to lanceolate (or to subrhombic) or linear, $2-8(-15)$ by $0.5-3(-4.5) \mathrm{cm}$, margin of the lamina dentate to denticulate, at least two teeth in the upper part of the lamina; lateral veins 5-10 pairs, but if the lamina is linear (willow-leaf-shaped), then up to 30 pairs.

Distribution - New Guinea (eastern).

Habitat - Primary (or secondary) forest at altitudes between (1600-)2400 and $3000 \mathrm{~m}$, occasionally on limestone.

Note - For this subspecies, a form with linear laminas and (therefore) numerous lateral veins has been described as $S$. urophyllus var. salicifolius Corner. 


\section{ACKNOWLEDGEMENTS}

The Flora Malesiana Foundation supported the preparation of the treatment of Moraceae for Flora Malesiana. Dr. J.F. Veldkamp (Leiden) translated the diagnoses into Latin.

\section{REFERENCES}

Berg, C.C. 1977. The Castilleae, a tribe of the Moraceae, renamed and redefined due to the exclusion of the type genus Olmedia from the 'Olmedieae'. Acta Bot. Neerl. 26: 73-82.

Berg, C.C. 1986. The delimitation and subdivision of the genus Maclura (Moraceae). Proc. Kon. Akad. Wetensch., Ser. C 89: 241-247.

Berg, C.C. 1988. The genera Trophis and Streblus (Moraceae) remodelled. Proc. Kon. Akad. Wetensch., Ser. C 91: 345-362.

Berg, C.C. 1998. Phytogeography, systematics and diversification of African Moraceae compared with those of other tropical areas. In: C.R. Huxley, J.M. Lock \& D.F. Cutler (eds.), Chorology, taxonomy and ecology of the floras of Africa and Madagascar: 131-148. Kew.

Berg, C.C. 2001. Flora Neotropica Monograph 83: Moreae, Artocarpeae, Dorstenia (Moraceae). With introductions to the family and Ficus and with additions and corrections to Flora Neotropica Monograph 7: 1-346. The New York Botanical Garden, New York.

Berg, C.C. 2004. Flora Malesiana precursor for the treatment of Moraceae 6: Ficus subgenus Sycomorus. Blumea 49: 155-207.

Berg, C.C. 2005a. Ficus (Moraceae). Flora Malesiana, Series 1, Spermatophytes 17, 2: 1-702. Foundation Flora Malesiana, Leiden.

Berg, C.C. 2005b. Moraceae diversity in a global perspective. Biol. Skr. 55: 423-440.

Bisset, N.G. 1957. Cardiac glycosides Part III. Moraceae: The genus Antiaropsis K. Schum. Ann. Bogor. 2: 219-223.

Brown, R. 1818. Appendix 5: Observations, systematical and geographical. In: J.K. Tuckey, Narr. Exped. Zaire: 420-485. Murray, London.

Chew, W.-L. 1989. Moraceae. Fl. Australia 3: 15-68. Australian Government Publishing Service, Canberra.

Corner, E.J.H. 1962. The classification of Moraceae. Gard. Bull. Singapore 19: 187-252.

Corner, E.J.H. 1970. New species of Streblus and Ficus (Moraceae). Blumea 18: 393-411.

Corner, E. J.H. 1975. The evolution of Streblus Lour. (Moraceae): with a new species of sect. Bleekrodea. Phytomorphology 25: 1-12.

Corner, E.J.H. 1976. A new species of Parartocarpus Baillon (Moraceae). Gard. Bull. Singapore 28: $183-190$.

Corner, E.J.H. 1978. Ficus dammaropsis and the multibracteate species of sect. Sycocarpus. Trans. Roy. Soc. London B, 281: 373-456.

Datwyler, S.L. \& G.D. Weiblen. 2004. On the origin of the fig: phylogenetic relationships of Moraceae from ndhF sequences. Amer. J. Bot. 91: 767-777.

Diels, L. 1935. Die Moraceen von Papuasien. Bot. Jahrb. Syst. 67: 171-235.

Go, R. 1998. A new species of Parartocarpus (Moraceae) from Sabah. Sandakania 12: 1-5.

Hallé, F. \& R.A.A. Oldeman. 1970. Essai sur l'architecture et la dynamique de croissance des arbres tropicaux. Masson, Paris.

Hegnauer, R. 1969. Chemotaxonomie der Pflanzen 5. Birkhäuser Verlag, Basel \& Stuttgart.

Jarrett, F.M. 1959a. Studies in Artocarpus and allied genera, I. General considerations. J. Arnold Arbor. 50: 1-29.

Jarrett, F.M. 1959b. Studies in Artocarpus and allied genera, II. A revision of Prainea. J. Arnold Arbor. 50: 30-37.

Jarrett, F.M. 1959c. Studies in Artocarpus and allied genera, III. A revision of Artocarpus subgenus Artocarpus. J. Arnold Arbor. 50: 113-368.

Jarrett, F.M. 1960a. Studies in Artocarpus and allied genera, IV. A revision of Artocarpus subgenus Pseudojaca. J. Arnold Arbor. 51: 73-140. 
Jarrett, F.M. 1960b. Studies in Artocarpus and allied genera, V. A revision of Parartocarpus and Hullettia. J. Arnold Arbor. 51: 320-340.

Kochummen, K.M. 1998. New species and varieties of Moraceae from Malaysia. Gard. Bull. Singapore 50: 197-219.

Miquel, F. A.W. 1853. Urticineae. In: C.F.P. von Martius, Fl. Bras. (Martius) 4, 1: 78-218. Oldenburg, Leipzig.

Nguyên, T.H. 1997. Une espèce nouvelle de Streblus (Moraceae) au Viêtnam: Streblus vidalii T.H. Nguyên. Adansonia, sér. 3, 19: 263-265.

Sakai, S. 2001. Thrips pollination of androdioecious Castilla elastica (Moraceae) in a seasonal tropical forest. Amer. J. Bot. 88: 1527-1534.

White, C.T. 1933. Ligneous plants collected for the Arnold Arboretum in North Queensland by S.F. Kajewski in 1929. Contr. Arnold Arbor. 4: 5-113.

Zerega, N.J.C., L.A. Mound \& G.D. Weiblen. 2004. Pollination in the New Guinean endemic Antiaropsis decipiens (Moraceae) is mediated by a new species of thrips, Thrips antiaropsidis spec. nov. (Thysantoptera: Thripsidae). Int. J. Pl. Sci. 165: 1017-1026. 